\title{
VERSITA
}

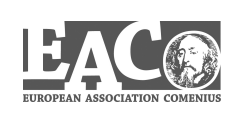

\section{Social Investment as a New Paradigm of Social Policy}

\section{Iveta Dudová ${ }^{1}$}

\begin{abstract}
The objective of this paper is to evaluate the importance and potential benefits of social investment, particularly during times of economic imbalance. Social investment represents a new paradigm of social policy and a new approach to the economic challenges we are currently facing. The investigation concludes that this concept is based mainly on modernizing Europe's social protection systems to ensure their sustainability, while enabling them to respond to new social needs. In times of crisis, the concept of social investment allows it to be seen in a new context as a new opportunity, because the crisis puts pressure on European countries to change their social models. In terms of long-term social policy, there must be a collective investment strategy that shapes the ability of individuals and families so that they can cope with new social risks and new economic conditions. A social investment pact should promote a positive path for the development of public policies in a situation where European states are facing budget deficits and a debt crisis. The modernizing of social policy requires that decisions on funding are led by results ex ante and systematically address the role of social policies in the various stages of an individual's life.
\end{abstract}

\section{Keywords}

Social Investment, Social Policy, New Social Risks, Human Capital, Social Investment Pact

\section{Introduction}

Europe is in a situation where individual countries increasingly lack resources. Disputes over spending include social and economic priorities. At present, there is increased pressure on governments to take measures which have a long-term social impact. The persistence of high levels of unemployment, polarization of income and growth of social exclusion increases the sense of insecurity in the whole population. Furthermore, Europe will, in the long term, meet with global competition, demographic and population changes and

${ }^{1}$ School of Economics and Management in Public Administration in Bratislava, Furdekova 16, 85104 Bratislava, Slovakia. Email: iveta.dudova@vsemvs.sk. 
problems in social cohesion. In addition to the impact of the crisis, the labor market is significantly changing in the context of the knowledge economy, altering the skills and qualifications required and putting large social groups at risk of poverty.

The last ten years of the 20th century saw the emergence of the concept of social investment in Europe, which was expressed as a desire to modernize European social protection systems and guarantee their sustainability, thus enabling them to respond to new social needs. The authors, who are dealing with issues of social investment, agree on this point. Those who advocate liberal approaches emphasize that the social investment state should replace the traditional welfare state. Authors with a social democratic orientation introduce social investment more as extension of existing policies, wherein a policy of support will amplify protection policies.

The objective of this paper is to evaluate the importance and potential benefits of social investment, particularly during economic imbalances.

Expenditure under the different branches of social security spending can be more or less regarded as capital expenditure. Family policy can be viewed as an investment to the extent that it contributes to fertility and female employment. Sickness security contributes to maintaining the workforce in good health and prevents the deterioration of human capital in terms of prevention. By contrast, spending on pensions is difficult to define as an investment.

European social policy has gradually formed an OMC (open method of coordination), access to which can support social policy as a policy of social investment in EU Member States. Social investment policies differ in how they use the different tools of social security. Social security coverage is carried out mainly by being paid in cash intended to compensate for loss of income or costs. The fight against new risks involves the introduction of services such as childcare, additional training, support for job seekers and aid to dependent older people.

\section{The importance of social investment during economic imbalances}

In times of crisis, the approach to the concept of social investment has a new context. The crisis is forcing states to redefine their social models. The basic idea of social investment is based on the perception of social protection as a productive factor and it is inspired by the theory of investment in human capital. This view emphasizes the need to enhance both the quantity and quality of human capital.

In terms of quantity, the task is to ensure the participation of the largest number of people needed for production, the promotion of fertility, increasing the number of women and older workers in employment, and preventing the long-term exclusion of certain persons from the labor market.

In terms of improving the quality of human capital, it is necessary to invest in education throughout life, from early childhood through to professional training and development, and to improve the quality of jobs.

Social investment is a reaction to the current economic and social problems. From an economic point of view, it deals with a new definition of the social protection concept 
adapted to the conditions of a knowledge economy, which differ from the original model associated with the development of mass production. This new model must be adapted to the particular needs of an economy with more intensive qualifications.

According to Delors and Dollé (2009), more than just mitigating the consequences of new risks and social issues that affect an individual's career path, it is necessary to seek to prevent their causes. Social investment is a new configuration of policy between the state, markets and individuals. It is a policy of social investment in individuals and efficient and transparent prevention. Social expenditure cannot be considered compensation for expenses, but as capital expenditure to build new capabilities of the individual, enabling him to be more independent in a competitive society.

In social terms, its task is to ensure the coverage of new social risks. Social protection systems were created in order to cover risks such as sickness, old age, childbirth, accidents and occupational diseases and unemployment. These risks continue to exist today, but new social risks are also being created. For example, poor, insufficient or outdated qualifications can lead to high long-term unemployment. Responsibility for children is perceived not from the costs point of view, as it is mostly dealt with by traditional family policy, but as a threat to the employment of women. Other risks are the dependency of elderly people, or single-parent households, which are becoming a significant factor in poverty and the intergenerational transmission of poverty and which can permanently exclude part of the population from the labor market.

New social risks increasingly affect younger populations. This requires the reallocation of social expenditure towards services for family, an active labor market policy, pre-school education for children and vocational education, so as to ensure increased productivity and a high level of employment of men and women in the knowledge economy. Explicit care during the active phase of life also affects sustainable pensions. Good pension policy begins at birth (Esping-Andersen, Gallie, Hemerijck and Myles, 2002).

An investment strategy focused on children determines their chances in life. Access to affordable quality child care is a prerequisite for the future functioning of balance. Demand for childcare cannot adequately be met by the market. In a pure market mode, low-income parents cannot ensure quality care. A lack of available care can result in a low birth rate. The underemployment of women raises child poverty. Childcare is essential for achieving a balance between work and family. An investment strategy concentrated on children also enhances lifelong learning and contributes to the development of a knowledge society (Vandenbroucke, Hemerijck and Palier, 2011).

The reconfiguration of social policy aimed at children is not only motivated by demographic trends. The social knowledge that supports this new policy is based primarily on the approaches of psychologists, health professionals, sociologists, and so on. Quality investment in children aimed at education and training promotes the development of future citizens who will be healthy, engaged and productive.

Differences in family background are a key factor affecting differences in initial knowledge when entering school and differences in the learning process during the early stages of the education of the individual. Return on investment in education is highest in the early stages, particularly in children from socially-disadvantaged families. Early intervention in the 
educational system becomes a question of ensuring equal opportunities for all children and also increasing the efficiency of education (Woessmann and Schuetz, 2006). It is therefore important to establish and institutionalize general early childhood education, particularly for those who are disadvantaged and have a stimulating educational environment at home. Ensuring adequate early childhood education and the provision of incentives for participation in education are very important, especially for the socially disadvantaged. This also applies to individuals with a migrant background. Given the expected influx of immigrants in the EU in the future, the integration of this population group becomes even more challenging. Education can serve as the basis for social integration and as the best guarantee against possible exclusion, unemployment and discrimination. The concept of learning strategies to better support children of immigrants in schools is therefore important.

Helping children and young people is an investment in a stronger society and economy. At the same time, however, state expenditures on measures in the form of aid for those who the new knowledge economy marginalizes are necessary. Low attendance percentages in school and the dropping out of school are among the most important factors explaining social exclusion.

The current structure of the aging workforce population is likely to affect the overall labor supply. Investment in human capital is often regarded as a key policy in maintaining the elderly in the labor market and increasing their productivity. Despite the potential importance of education, training incentives decrease with age. One reason for this is that the remaining time to be spent in the labor market is often too short to offset the cost of the investment, especially if these costs are paid by the employer. Changing the age of retirement or pension reforms that reduce the implicit tax on continuing work and raising the minimum retirement age may improve incentives to invest (Schlotter, Schwerdt and Wößman, 2008). Given the expected decline and aging of the workforce, it is essential to fully exploit the full potential of human resources, i.e. youth.

Global competition exerts more pressure to maintain social cohesion in Europe. Given that the expansion of education is very important in order to reduce social inequalities, the education system is a key institution affecting social cohesion. In Europe, it is therefore necessary to promote social cohesion through investment in education systems. The expected future decline in demand for unskilled labor will continue to increase the importance of education in addressing social inequalities. Education can act as the basis for social integration.

Europe's competitiveness in a knowledge economy requires investment in human capital throughout the lifetime of a person. Given the demographic imbalance, the lack of skills needs to be addressed. Social and employment policies are increasingly focused on the development of quality human resources with a good balance of skills. The relationship between economic performance and the social state are mediated through the labor market. The EU therefore supports the development of flexicurity in Member States.

\section{European support for social investment}

The economic crisis has had an impact on public finances and sparked efficient solutions in public budgets. The boundaries of social spending decrease due to the level of social debt, 
an aging population and medical technological progress, which significantly increases the total cost of covering the risk of old age, illness and addiction. More generally, insufficiently covered needs (children, disability) and new demands (the reconciliation of work and family life, the providing of career paths, demand for training and retraining programs) are subject to new expectations.

The Lisbon agenda requires a social investment strategy, while the Europe 2020 program supports the idea of social investment. Globalization is a frame of reference that defines modern EU objectives. Europe's response to globalization reflects the increasingly accepted view that, since equal outcomes for citizens cannot be guaranteed, equal opportunities are an insufficient goal, unless accompanied by strong efforts to ensure that all citizens have access to the same resources, conditions and capabilities.

In March 2011, the European Council adopted a comprehensive package of measures aimed at responding to the crisis, preserving financial stability and laying the foundations for intelligent, sustainable and socially inclusive growth, aimed at supporting job creation. The agreed priorities for fiscal consolidation and structural reforms gave priority to restoring sound budgets and fiscal sustainability, reducing unemployment through labor market reforms and boosting growth. These priorities are reflected for individual Member States in their Stability or Convergence Programs and National Reform Programs. On that basis, the Commission presents suggestions for opinions.

Fiscal policies in 2012 were aimed at restoring confidence and gradually returning to sustainable debt levels and reducing the deficit below $3 \%$ within the agreed timeframe. Consolidation has become a priority, especially in those Member States which have a very high structural deficit and very high, or respectively rapidly increasing, levels of public debt.

The objectives of the measures implemented under the structural reforms focused on making work more attractive, helping the unemployed return to work, fighting against poverty and promoting social inclusion, investment in education and training, establishing a balance between security and flexibility, pension reforms, attracting private capital to fund growth, support for research and innovation, and promoting policies in energy efficient areas.

Part of a package of measures from March 2011 was the Euro Plus Pact, with the goal of strengthening the economic pillar of the EMU, achieving a new standard of economic policy coordination and increasing the rate of convergence, increasing competitiveness, employment and the sustainability of public finances, thus strengthening financial stability. The Europe 2020 strategy set out to increase the employment rate of people aged 20-64 years to $75 \%$ in 2020 , reduce to under $10 \%$ the share of early school leavers, ensure at least $40 \%$ of the population aged 30-34 years have a university degree and reduce by at least 20 million the number of people at risk of poverty and social exclusion.

Slovakia has agreed to increase the employment rate of people aged 20-64 years to 72\%, reduce to under $10 \%$ the share of early school leavers, ensure that at least $40 \%$ of the population aged 30-34 years have a university degree and reduce the number of people at risk of poverty and social exclusion by at least 170,000 . The current results achieved in all European states are presented in Table 1. 
Table 1: Selected Europe 2020 Indicators in 2012

\begin{tabular}{|c|c|c|c|c|}
\hline Countries & $\begin{array}{l}\text { Employment rate for } \\
\text { 20-64 age group } \\
\text { (\% of population } \\
\text { aged } 20-64)\end{array}$ & $\begin{array}{l}\text { Early leavers from } \\
\text { education and training } \\
\text { (\% of population } \\
\text { aged } 18-24)\end{array}$ & $\begin{array}{c}\text { Tertiary educational } \\
\text { attainment } \\
\text { (\% of population } \\
\text { aged } 30-34)\end{array}$ & $\begin{array}{c}\text { People at risk of } \\
\text { poverty or social } \\
\text { exclusion (\% of total } \\
\text { population) }\end{array}$ \\
\hline$\overline{\mathrm{EU}}(27$ countries $)$ & 68.5 & 12.8 & 35.8 & 24.2 \\
\hline Belgium & 67.2 & 12.0 & 43.9 & 21.0 \\
\hline Bulgaria & 63.0 & 12.5 & 26.9 & 49.1 \\
\hline Czech Republic & 71.5 & 5.5 & 25.6 & 15.3 \\
\hline Denmark & 75.4 & 9.1 & 43.0 & 18.9 \\
\hline Germany & 76.7 & 10.5 & 31.9 & 19.9 \\
\hline Estonia & 72.1 & 10.5 & 39.1 & 23.1 \\
\hline Ireland & 63.7 & 9.7 & 51.1 & $:$ \\
\hline Greece & 55.3 & 11.4 & 30.9 & 31.0 \\
\hline Spain & 59.3 & 24.9 & 40.1 & 27.0 \\
\hline France & 69.3 & 11.6 & 43.6 & 19.3 \\
\hline Italy & 61.0 & 17.6 & 21.7 & 28.2 \\
\hline Cyprus & 70.2 & 11.4 & 49.9 & 23.7 \\
\hline Latvia & 68.2 & 10.5 & 37.0 & 40.4 \\
\hline Lithuania & 68.7 & 6.5 & 48.7 & 33.4 \\
\hline Luxembourg & 71.4 & 8.1 & 49.6 & 16.8 \\
\hline Hungary & 62.1 & 11.5 & 29.9 & 31.0 \\
\hline Malta & 63.1 & 22.6 & 22.4 & 21.4 \\
\hline Netherlands & 77.2 & 8.8 & 42.3 & 15.7 \\
\hline Austria & 75.6 & 7.6 & 26.3 & 16.0 \\
\hline Poland & 64.7 & 5.7 & 39.1 & 27.2 \\
\hline Portugal & 66.5 & 20.8 & 27.2 & 24.4 \\
\hline Romania & 63.8 & 17.4 & 21.8 & 40.3 \\
\hline Slovenia & 68.3 & 4.4 & 39.2 & 19.3 \\
\hline Slovakia & 65.1 & 5.3 & 23.7 & 20.6 \\
\hline Finland & 74.0 & 8.9 & 45.8 & 17.9 \\
\hline Sweden & 79.4 & 7.5 & 47.9 & 16.1 \\
\hline United Kingdom & 74.2 & 13.5 & 47.1 & 22.7 \\
\hline
\end{tabular}

Source: Eurostat

Reducing fiscal deficits has affected public spending and raised questions as to whether such measures can indeed promote economic growth. The unemployment rate in the EU was up from about 7\% in 2008 to more than $10 \%$ in 2013 (in May 2013, it was $10.4 \%$, $12.1 \%$ in the euro area), and there are distinct differences between different regions. The increase mainly affects young people (in May 2013, there were a total of 5,501 million people younger than 25 years unemployed, of which 3,531 million were in the euro area), the low-skilled and long-term unemployed. This situation, of unemployment combined with an aging population, creates a serious risk of a loss of human capital in the long term. It can create difficult to resolve impacts on the labor market and on social cohesion. The level of education and training in the EU, due to the lack of resources invested, is unable to meet the labor market's future qualification and skill needs.

Experts have begun to put forward the opinion that social investment is a necessity which may contribute to the development and achievement of well-defined strategic objectives for 2020. Social investment is seen as a new paradigm of social policy and a new approach to the economic challenges currently facing European countries. 
The European Parliament endorsed these investment-based approaches to social policy, and in 2012 adopted a resolution on the Social Investment Pact in response to the crisis. The definition of social investment perspective assumes the provision of funds which are then used to create social and economic gains designed to address emerging social risks and unmet needs and focus on investment strategies in public policies and in the area of human resources, thus helping individuals, families and society gain the ability to adapt to changing social and economic conditions, including changes in labor markets and future demand for knowledge and skills in jobs. As social services can all be considered public social and health services, educational services and services in these areas can be provided by private entities. These services are defined by national legislation.

The Committee on Employment and Social Affairs of the European Parliament, in its report on the Social Investment Pact - in response to the crisis (A7-0263/2012), states that goal-oriented social investments should be part of national and European policies on the economy and jobs, because they have the ability to mutually align social and economic objectives. Essential elements of social investments can include social entrepreneurship and access to microfinance for vulnerable groups and individuals excluded from the labor market. New jobs created on this basis are sustainable because they are largely resistant to fluctuations in the economic cycle.

The Commission adopted a recommendation entitled "Investing in children: a way out of the vicious circle of disadvantage", as part of a social investment in February 2013. Member States have their needs met by a combination of cash and material rations and through accessible quality early childhood education, healthcare and social services. The task is to eliminate inequality between children through the prevention of school segregation and education on the abuse of students with special educational needs.

In its opinion on the Stability Program of Slovakia for the years 2012-2016, the Council, in relation to social investments, recommends that the following measures are carried out in 2013 and 2014. Preventing spending cuts to promote growth and intensifying efforts to improve the efficiency of public spending. Taking measures to improve the capacity of public employment services and provide jobseekers with personalized services and strengthening the link between activation measures and social assistance. Finding effective ways to address long-term unemployment through activation measures and individualized training. Improving the provision of childcare facilities, especially for children under three years of age. Reducing the tax burden for those with low incomes and adjusting system benefits. Intensifying efforts to address high youth unemployment, for example through guarantees for young people. Taking measures to attract young people to the teaching profession and improving learning outcomes. In vocational education and training, strengthening the provision of practical training in-house. In higher education undergraduate programs, an increased focus on jobs. Intensifying efforts to improve access to high quality and inclusive pre-school and school education of marginalized communities, including the Roma. 


\section{Social investment through the European budget}

Legislative proposals in the field of European regional policy, social policy and employment policy, for 2014-2020 in particular, promote social investments that allow people to face the challenges of the labor market, and, with the support of the European Globalisation Adjustment Fund, adapt to globalization and to the new program for social change and innovation, complementing and reinforcing the European Social Fund.

The proposal made by the European Social Fund in 2011 should improve employment opportunities, promote education and lifelong learning and develop policies for active inclusion, and thereby contribute to economic, social and territorial cohesion in accordance with Article 174 of the Treaty. In accordance with Article 9 of the Treaty, the European Social Fund should take into account requirements linked to the promotion of a high level of employment, the guarantee of adequate social protection, the fight against social exclusion, and a high level of education, training and protection of human health.

The European Social Fund should focus on promoting employment and labor mobility, investment in education, skills and lifelong learning, promoting social inclusion and combating poverty. The European Social Fund to support the European Employment Services (EURES) should in particular promote the better functioning of labor markets by enhancing the geographical mobility of workers.

Additional to these priorities should be the aim of fostering economic growth and improving employment opportunities in less developed regions. Member States should increase the efficiency of public administration and should strengthen the institutional capacities of those parties which deliver employment, education and social policies.

One of the main thematic objectives of the European Social Fund should be to help people acquire necessary skills and lifelong learning, and to adapt to new challenges such as the information society, the knowledge economy and the transition to a low carbon and energy-efficient economy. In this context, the European Social Fund aims to support the transition of the labor force towards greener skills and jobs, particularly in areas of energy efficiency, renewable energy and sustainable transport, and also take into account the Union's intention to increase the share of the EU budget which is associated with the inclusion of climate issues into other policy areas to at least $20 \%$, with contributions from different policy fields.

Implementation of the programs financed by the European Social Fund should contribute to the promotion of gender equality and gender mainstreaming and should take into account in all dimensions of the programs, while ensuring that specific actions are taken to promote gender equality. In addition, the implementation of the priorities financed by the Fund should also contribute to the broader fight against discrimination on the grounds of sex, racial or ethnic origin, religion or belief, disability, age or sexual orientation.

Another area supported by the European Social Fund is the support of social innovation, which is an important factor in formulating policies more responsive to social change and promoting innovative social enterprises. 
The European Commission supported a social investment pact, while in its communication "Towards social investment in growth and cohesion - including the implementation of the European Social Fund in 2014-2020" from February 2013, it suggested that, in the period 2014-2020, the European Social fund set aside at least 25\% of cohesion policy resources for human capital and social investment. It also suggested that at least $20 \%$ of the total resources of the Fund in each Member State should be allocated to the thematic objective of promoting social inclusion and combating poverty.

In the programming period 2007-2013, the European Social Fund has contributed to more than 50 million people. In 2011, this included more than 4.5 million unemployed and 5 million inactive people. The fund spent $€ 75$ billion to acquire better skills and increase employability, while individual programs contributed to mitigating the negative effects of the crisis and preserving jobs. Measures aimed at the social integration of the European Regional Development Fund attracted 18 billion euro, aimed in particular at promoting education and investment in health and social infrastructure.

In implementing the strategy set out in the package of social investments that are available to Member States, important tools such as European structural and investment funds, especially the European Social Fund and the Progress program for the period 2007-2013, the Program for Social Change and Innovation 2014-2020 and the European Fund aid to the most deprived. In addition, financial support under the Cohesion Policy, which aims to strengthen economic, social and territorial cohesion throughout the Union will be an important tool to achieve the objectives of Europe 2020 in the programming period 2014-2020.

The European Commission, in support of inclusive growth, called on Member States to ensure that their policies on employment, human capital development, the modernization of public services, regional investment and social inclusion reflect country-specific recommendations, as well as an initial analysis of the major challenges described in the job SWD, assessing national reform programs and stability programs.

Funding under the European Social Fund may be supplemented by additional funding from the European Regional Development Fund, particularly for investment in health, social care, child care, infrastructure, housing and education and to promote the physical and economic regeneration of deprived urban and rural communities. These investments may also contribute to the reform of social policies on issues such as desegregation in educational establishments, the transition to community care and integrated housing policies.

The European Commission has put forward initiatives designed to help provide targeted and integrated social investment. These include the following forms of investment. Measures to stimulate social investment funding, in addition to resources from the Structural Funds, also include new funding instruments which could be used to facilitate fiscal consolidation through the greater involvement of private funding. 
a) Support for access to finance for social enterprises: European Social Entrepreneurship Funds (the fund for social enterprises in the Program for Social Change and Innovation, which will become operational by 2014, will call on the so-called European Social Entrepreneurship Fund to assist in identifying funds that support European social enterprises.)

b) Survey of the use of new financial instruments, based on the fact that innovative financing social investment from the private and third sector complement the efforts of the public sector. The Program for Social Change and Innovation will continue to use the Progress Microfinance Facility, which will result from the 2014 budget of approximately 92 million.

c) Social impact bonds designed to encourage private investors to fund social programs by offering them income from the public sector, if a specific program achieves positive social outcomes.

The second area of action constitutes adequate livelihood support and raises awareness of social rights. Their aim is to ensure the proper administration regulations, improve awareness, providing targeted assistance to disadvantaged citizens. This includes the following measures.

a) Ensuring adequate livelihoods via minimum income schemes in Member States. Dignity is maintained for those involved and at the same time they are encouraged to gain income from employment.

b) Capacity building and streamlining efforts to create single points of contact to simplify organization, improve performance and increase the use of services.

c) Strengthening financial inclusion, which should support the directive on access to a payment account with basic functions.

d) Protecting people from financial difficulties in terms of prevention to alleviate financial difficulties and combat homelessness, which may be the result of irresponsible lending and borrowing.

e) Energy efficiency, which concerns the Directive to encourage Member States to include in their national systems socially-oriented requirements. The Directive takes into account the special needs of disadvantaged individuals and contributes to the elimination of so-called energy poverty, while introducing intelligent measures and clear, informative accounts.

f) Improving public access to information concerning social rights, such as job searching, unemployment benefits, child benefits, health care and student grants.

The third group of measures represent investments in child care, education and early childhood. Social investment should be focused on early intervention through first improving access to childcare and second, reducing the number of early school leavers. Reducing the number of early school leavers is among the investment priorities of the European Social Fund and this may be used by Member States to develop appropriate policies. Promoting investment in human capital will also be supported by the new Erasmus for All program. 
Member States, in promoting children's access to health and social services, education and early childcare, may, in the context of the implementation of recommendations for investment in children, make use of the resources of the European Social Fund, European Regional Development Fund and the European Agricultural Fund for Rural Development.

\section{Conclusion}

The concept of social investment reflects a long-term perspective of social policy. This approach emphasizes that social policy requires a collective investment strategy that prepares individuals and families to cope with new social risks and new economic conditions. The idea of social investment is future-oriented and presents a way to develop a knowledgebased economy. To facilitate its emergence, the focus needs to be on children who will enter the labor market in the future and this constitutes an essential element of the modernization of social policy. The knowledge society will be determined in the future by the creation of the information society and by the use of computerized communication systems, by the ability of individuals to create, obtain, concentrate and use knowledge and social and technological changes that are linked to new technologies.

All these factors will have significant impact on the character of society. Already there is a growing trend towards individualization, to a new model of family life, while the status of women in society is changing and new material interests of citizens are emerging. The concept of a social investment strategy of social policy can be a useful contribution to how to adapt to the expected social and economic changes.

The economic crisis requires us to solve the problems of many countries which are facing budget deficits and debt. This is one aspect of public policy. On the other hand, at the same time there is an increasing need for countries to invest in their future. Through European funding, such as through the Structural Funds, Europe can support social investment policy. Despite the debt crisis, the European Union can ensure that Member States have agreed on a policy of social investment and find ways to do so. The social investment pact will promote investment in quality child care for children, education and continuing education for all, improving working conditions and quality of jobs, including for disadvantaged groups. It is necessary to increase support for education, training and the integration of migrants into the labor market and create a safety net for all.

\section{References}

Delors. J. and Dollé, M. (2009). Manifeste pour une politique sociale - Investir dans le social. Paris: Odile Jacob.

Esping-Andersen, G., Gallie, D., Hemerijck, A. and Myles, J. (2002). Why We Need a New Welfare State. Oxford: Oxford University Press.

European Commission. (2013). Investing in Social Europe. Luxembourg: Publications Office of the European Union.

Giddens, A., Diamond, P. and Liddle, R. (2006). Global Europe, Social Europe. Cambridge: PolityPress. 
Schlotter, M., Schwerdt, G. and Wößman, L. (2008). The Future of European Education and Training Systems: Key Challenges and Their Implications. EENEE Analytical Report No. 3 prepared for the European Commission.

Vandenbroucke, F., Hemerijck, A. and Palier, B. (2011). The EU Needs a Social Investment Pact. OSE Paper Series, Opinion paper No. 5, May 2011.

Wößmann, L. and Schütz, G. (2006). Efficiency and Equity in v European - Education and Training Systems. EENEE Analytical Report No. 1 prepared for the European Commission. 